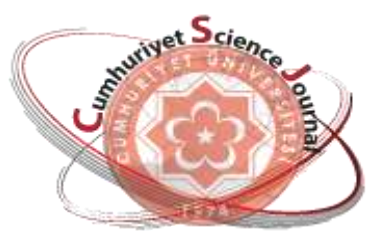

e-ISSN: $2587-246 X$

ISSN: $2587-2680$

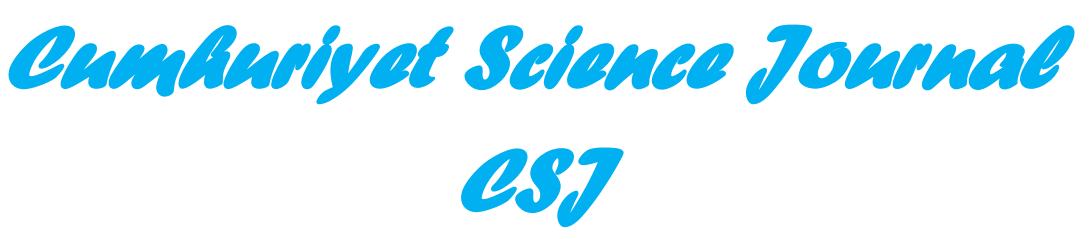

Cumhuriyet Sci. J., Vol. 39-1 (2018) 218-232

\title{
Preconcentration of Iron in Some Drug and Water Samples by Coprecipitation with Magnesium Hydroxide Before Spectrophotometric Determination
}

\author{
Cemalettin UYAN*, Ersin BEKCIOGULLARI \\ Cumhuriyet University, Faculty of Science, Department of Chemistry, Sivas, TURKEY
}

Received: 15.11.2017; Accepted: 09.03.2018

http://dx.doi.org/10.17776/csj.353455

\begin{abstract}
A method was purposed for preconcentration and determination of iron, in this study. The method consist of these steps respectively: I) Coprecipitation of the iron present in the sample with $\mathrm{Mg}(\mathrm{OH})_{2}$ collector. II) Seperation of the precipitate by centrifuging. III) Solving the precipitation in acid. IV) UV-VIS spectrophotometric determination of the iron concentrated in the resultant lower volume solution using its complexation with thiocyanate. The effects of factors such as centrifugation time, $\mathrm{pH}$ and $\mathrm{Mg}$ concentration on the absorbance signal were investigated and the optimum values of these factors were determined. Total iron in the sample was brought single oxidation state (Fe(II) or $\mathrm{Fe}(\mathrm{III})$ ) before coprecipitation procedure. Calibration curve was derived for both of the proceses. The detection limit and working range for the proposed method were found to be $0.01 \mathrm{mgL}^{-1}$ and $0.03-0.3 \mathrm{mgL}^{-1}$ respectively. The proposed method was applied to tap water, mineral water samples and Rennie anti-acid drug tablet. The accuracy of the method was tested by analyte spiked method. The accuracy results in terms of Recovery \% are between $90-100 \%$. Mostly the relative standart deviations (RSD \%) values do not exceed $5 \%$.
\end{abstract}

Keywords: Iron determination, preconcentration, coprecipitation, $\mathrm{Mg}(\mathrm{OH})_{2}$ collector, UV-VIS absorpsiyon spectrophotometric method.

\section{Bazı ilaç ve Su Örneklerinde Demirin Spektrofotometrik Tayin Öncesi Mağnezyum Hidroksit ile Birlikte Çöktürme Yoluyla Önderiştirilmesi}

\begin{abstract}
Özet: $\mathrm{Bu}$ çalışmada demir için bir önderiştirme ve tayin yöntemi önerilmektedir. Yöntem sırasıyla şu adımlardan ibarettir: I) $\mathrm{Mg}(\mathrm{OH})_{2}$ kollektörüyle örnekteki demirin birlikte çökmesi II) Oluşan çökeleğin santrifüjlenerek ayrılması, III) Çökeleğin asitte çözülmesi IV) Elde edilen daha düşük hacimli çözeltide deriştirilmiş olan demirin tiyosiyanatla kompleksleşme yoluyla UV-VIS spektrofotometrik olarak tayin edilmesi. Santrifüjleme süresi, $\mathrm{pH}, \mathrm{Mg}$ derişimi gibi etkenlerin çökmeye veya absorbans sinyaline etkileri araştırılmış ve bu etkenlerin optimum değerleri belirlenmiştir. Örnekteki toplam demir, birlikteçöktürme öncesi tek bir yükseltgenme haline (Fe(II) or Fe(III)) dönüştürülmüştür. Prosesin her ikisi için kalibrasyon grafiği oluşturulmuştur. Yönteme ait $0.01 \mathrm{mgL}^{-1}$ tespit sınırı ve $0.03-0.3 \mathrm{mgL}^{-1}$ çalışma aralığı elde edilmiştir. Yöntem musluk suyuna, maden suyu örneklerine ve Rennie antiasit ilaç tabletine uygulanmıştır. Yöntemin doğruluğu analit aşılama yoluyla test edilmiştir. Elde edilen doğruluk değerlerinin çoğu yüzde geri kazanım olarak \% 90100 arasındadır. Tekrarlanabilirlik veya kesinlik için ise bağıl standart sapma olarak çoğunluğu \% 5'i geçmeyen değerler elde edilmiştir.
\end{abstract}

Anahtar Kelimeler: Demir tayini, demir önderiştirilmesi, birlikte çöktürme, $\operatorname{Mg}(\mathrm{OH})_{2}$ kollektörü, UV-VIS Spektrofotometrik metod.

\footnotetext{
* Corresponding author. Email address: cuyan@cumhuriyet.edu.tr

http://dergipark.gov.tr/csj C2016 Faculty of Science, Cumhuriyet University
} 


\section{INTRODUCTION}

The biological significance of the trace elements is widely investigated. Trace element determinations are of continuous importance due to their biological importance as well as the quality control of products manufactured in the industry, especially those of high purity.

Heavy metals are known as toxic. However, lower levels of some heavy metals are essential for human organism. One of them is iron. After entering to the organism, iron follows a complex path. Besides carrying oxygen by bonding it to hemoglobin, it exists in the structures of some vital enzymes.

The coprecipitation methods are a branch of the field of methods of seperation and enrichment. Such methods are usually based on adsorption, to be retained by a precipitate called as collector.

More than thirty types of collectors were used in this field studies. Those used before 1982 were compiled by Minczewski et al in tables to indicate the preconcentrated species and applied examples related to each one [1]. Most of ones used later are given in Table 10 (in this article); the studies shown in this table were chosen to include those related to the iron preconcentration after 1997. $\mathrm{Mg}(\mathrm{OH})_{2}$ is one of the collectors used in this field. The studies on the use of this collector for the iron preconcentration are consisted of the seperation of iron from metallic lead sample and its determination by o-phenanthroline extraction spectrophotometric method [2], the preconcentration of iron in ocean water and its determination by ICP-MS (See Table 10, references $6,16,22$ )

A review of the literature has revealed that there is no study that used the simple UV-VIS spectrophotometric method among the iron determination methods after proconcentration. It also has been found that there is no study which uses drug sample in preconcentration methods by coprecipitation. It should be noted that preconcentration and determination of a trace type that is unmentioned in drug prospectuses is of particular importance. The study in this article involves the preconcentration of iron by coprecipitation. In the present study, an alternative method for the preconcentration and determination of iron has been purposed. This alternative method employs iron as analyte, $\mathrm{Mg}(\mathrm{OH})_{2}$ as collector, and a simple UV-VIS spectrophotometric as a method of analysis. As a simple UV-VIS spectrophotometric method, well-known thiocyanate complexation method was chosen. By doing so, it is aimed to bring the advantages of coprecipitation and UV-VIS spectrophotometric methods together so that they will complement each other. It is believed that this method will be useful for such demands of the institutions with shoestring budgets that conduct routine analysis. Furthermore, the proconcentration and determination of iron was handled in Rennie anti-acid tablet for the first time. The $\mathrm{Fe}$ impurity detected by the proconcentration in this drug tablet is a beneficial impurity thanks to the biological importance of iron.

\section{EXPERIMANTAL}

\subsection{Apparatus}

UV-VIS Spectrophotometer: UNICAM UV / VIS Spectrometer UV 2

Centrifuge: Hettich Rotofix, 32A and Hettich Universal 320

PH meter: Adwa AD8000

\subsection{Reagents and solutions}

All solutions were prepared from analytical grade Merck liquid and solid agents. Double distilled 
water was used as solvent water. 1) Fe(II) and Fe (III) Standards: a) Stock solutions, which each was $1000 \mathrm{mgL}^{-1}$ concentration, were prepared from iron salt, weighted solid was dissolved in 0,01 M HCI. b) $10 \mathrm{ppm} \mathrm{Fe}$ (II) and Fe(III) standards were prepared from these stock solutions. The mediums of these diluted solutions were created with about $0.01 \mathrm{M}$ HCI (iron hydroxide precipitation was seen in even $10 \mathrm{mgL}^{-}$

${ }^{1}$ concentration when not being acidificated), 2) Solid $\mathrm{Na}_{2} \mathrm{SO}_{3}$ and as an alternative $2 \%(\mathrm{w} / \mathrm{V})$ $\mathrm{Na}_{2} \mathrm{SO}_{3}$, 3) $1 \mathrm{M} \mathrm{MgSO}_{4} 7 \mathrm{H}_{2} \mathrm{O} 100 \mathrm{~mL}$, 4) $6 \mathrm{M}$ $\mathrm{NaOH} 1000 \mathrm{~mL}$, 5) $2 \mathrm{M}$ HCI $1000 \mathrm{~mL}$, 6) $2 \mathrm{M}$ $\mathrm{HNO}_{3} 500 \mathrm{~mL}$, 7) Saturated $\mathrm{K}_{2} \mathrm{~S}_{2} \mathrm{O}_{8} \quad$ (Kperoxodisulfate) solution: Some grams were transferred to a small beaker by taking from the solid compound, it was mixed for a while after adding water, then it was waited. Upper clear solution was used. (This solution should not be more 3 days when it is used), 8)1.83 M KSCN, $100 \mathrm{~mL}$.

\subsection{Proposed method; preparing calibration curve and applying to the samples}

A series of $50 \mathrm{~mL}$ Falcon centrifuge tubes are obtained to use some of them for calibration curve and some others for samples. $10 \mathrm{mgL}^{-1} \mathrm{Fe}$ (the standard is chosen for $\mathrm{Fe}$ (II) or $\mathrm{Fe}$ (III) depending on for which one the calibration curve will be prepared) is added to the tubes at the rate of between $150-1500 \mu \mathrm{L}$ so as to achieve $0.03-0.3$ $\mathrm{mgL}^{-1} \mathrm{Fe}$ when diluted to $50 \mathrm{~mL}$. Following this, double distilled water is added to the tubes up to thick marks pointing $50 \mathrm{~mL}$. These $50 \mathrm{~mL}$ samples are added to the tubes chosen for samples. $1 \mathrm{M} \mathrm{MgSO}_{4}$ is added to the tubes for calibration curve according to Table 4. It should be noted that $\mathrm{MgSO}_{4}$ is not added to the sample if the $\mathrm{Mg}$ concentration in the analysed sample is known; if not known, $200 \mu \mathrm{L}$ is added. Thereafter, the $\mathrm{pH}$ of each solution is set to 12 . After waiting for 15-20 minutes, it is centrifuged at $4000 \mathrm{rpm}$ for 20 minutes. Following that, the supernatant solution is removeded. $4.0 \mathrm{~mL}$ of $2 \mathrm{M} \mathrm{HCl}$ is added to each tube. When all the precipitate dissolves, $100 \mu \mathrm{L}$ saturated $\mathrm{K}_{2} \mathrm{~S}_{2} \mathrm{O}_{8}$ solution and $900 \mu \mathrm{L} \mathrm{1,83} \mathrm{M} \mathrm{KSCN}$ are added and mixed. Absorbance values are taken from the UV-VIS spectrophotometer at $470 \mathrm{~nm}$.

\subsection{Sample preparation}

Sample preparation is performed in two means/roads: 1) Reduction: The total iron, which is assumed to be a mixture of $\mathrm{Fe}$ (II) and Fe (III) ions in the sample, is converted into Fe (II) and coprecipitated. 2) Oxidation: The total iron is converted into Fe (III) and coprecipitated as Fe (III). The calibration curve is prepared according to $\mathrm{Fe}$ (II) in the first and $\mathrm{Fe}$ (III) in the second.

\subsubsection{Tap water sample preparation}

1) Reduction road: I) About $1 \mathrm{~L}$ of tap water is added to a large beaker. II) It is filtered. III) Solid $\mathrm{Na}_{2} \mathrm{SO}_{3}(0.1-0.2) \mathrm{g}$ is added to the filtrate and it is mixed for an hour. As an alternative to solid reductant, it is $\mathrm{Na}_{2} \mathrm{SO}_{3}$ solution. Instead of adding only one time to orginal sample, $100 \mu \mathrm{L} \% 2$ $\mathrm{Na}_{2} \mathrm{SO}_{3}$ can be added to each tube after adding sample to tubes one by one.

2) Oxidation road: The step I and II described above are applied exactly. III) $2.5 \mathrm{~mL}$ of concentrated $\mathrm{HNO}_{3}$ and a tip of spatula (0.1 - 0.2 g) of solid potassium peroxydisulfate $\left(\mathrm{K}_{2} \mathrm{~S}_{2} \mathrm{O}_{8}\right)$ are added to $1 \mathrm{~L}$ of filtered sample to. IV) It is left to heat and mixed; it is mixed at least for an hour without exceeding $40{ }^{\circ} \mathrm{C} \mathrm{V}$ ) It is cooled to the room temperature. 
Table 1. The sample compositions.

\begin{tabular}{|c|c|}
\hline Samples species & Composition \\
\hline Model sample A & $\begin{array}{l}\text { As } m g L^{-1} \mathrm{Fe}(\mathrm{II}): 0.12, \mathrm{Fe}(\mathrm{III}): 0.08, \mathrm{Mg}(\mathrm{II}): 96, \mathrm{SO}_{4}{ }^{2-}: 0.21, \mathrm{NO}_{3}^{-}: 0.26 \text {, } \\
\mathrm{Cl}^{-}: 7.10\end{array}$ \\
\hline Model sample B & $\begin{array}{l}\text { As } m g L^{-1} \mathrm{Fe}(\mathrm{II}): 0.2, \mathrm{Cu}(\mathrm{II}): 0.1, \mathrm{Co}(\mathrm{II}): 1, \mathrm{Mg}(\mathrm{II}): 96, \mathrm{Mn}(\mathrm{II}): 1, \mathrm{Cr}(\mathrm{VI}): 1.2, \\
\mathrm{Cr}(\mathrm{III}): 1, \mathrm{Ni}(\mathrm{II}): 1.4, \mathrm{Hg}(\mathrm{II}): 0.4, \mathrm{Cd}(\mathrm{II}): 1.2, \mathrm{Ca}(\mathrm{II}): 8, \mathrm{Na}^{+}: 32.2 \mathrm{~K}^{+}: 63.5, \\
\mathrm{HCO}_{3}{ }^{-}: 61, \mathrm{SO}_{4}{ }^{2-}: 76.8, \mathrm{Ac}^{-}: 0.2, \mathrm{NO}_{3}^{-}: 6.7, \mathrm{Cl}^{-}: 14.2\end{array}$ \\
\hline C. Ü tap water & Unknown (no in formation available) \\
\hline $\begin{array}{l}\text { Beypazarı mineral } \\
\text { water }\end{array}$ & $\begin{array}{l}\text { As } m g L^{-1} \mathrm{Ca}(\mathrm{II}): 235.5, \mathrm{Mg}^{2+}: 108.4, \mathrm{Al}^{3+}: 0.0087, \mathrm{Na}^{+}: 265.2, \mathrm{~K}^{+}: 63.01, \\
\mathrm{NH}_{4}^{+}: 0.05, \mathrm{HCO}_{3}^{-}: 1865.4, \mathrm{SO}_{4}{ }^{2-}: 138, \mathrm{Cl}^{-}: 25.8, \mathrm{~F}^{-}: 0.46, \mathrm{NO}_{3}^{-}<1.0, \\
\mathrm{NO}_{2}{ }^{-}<0.005, \text { Silikat: } 62.5, \text { Fosfat: } 1.9 \text { (given on bottle) }\end{array}$ \\
\hline $\begin{array}{l}\text { Eskipinar mineral } \\
\text { water }\end{array}$ & $\begin{array}{l}\text { As } m g L^{-1} \mathrm{Ca}(\mathrm{II}): 235.5, \mathrm{Mg}^{2+}: 108.4, \mathrm{Na}^{+}: 265.2, \mathrm{~K}^{+}: 0, \mathrm{NH}_{4}^{+}: \text {yok, } \mathrm{HCO}_{3}^{-} \\
: 2501, \mathrm{SO}_{4}^{2-}: 26.4, \mathrm{Cl}^{-}: 30.7, \mathrm{~F}^{-}: 0.14, \text { no } \mathrm{NO}_{3}^{-}, \text {no } \mathrm{NO}_{2}^{-} \text {, no silicate, no } \\
\text { phophate (given on bottle) }\end{array}$ \\
\hline Rennie antiacid tablet & $\begin{array}{l}\text { Active ingredients: } 680 \mathrm{mg} \text { calcium carbonate, } 80 \mathrm{mg} \text { magnesium carbonate; } \\
\text { inactive ingredients: sugar, potato starch, pregelatinized corn starch, } \\
\text { magneisum stearate, talcum, liquid paraffin, light mint flavor, lemon flovar } \\
\text { (given in drug propectus). }\end{array}$ \\
\hline
\end{tabular}

\subsubsection{Mineral water sample preparation}

Table 2. Relations of sample type, $\mathrm{Mg}$ concentration, sample preparation method and calibration curve

\begin{tabular}{|c|c|c|c|c|}
\hline $\begin{array}{l}\text { Sample } \\
\text { species }\end{array}$ & $\begin{array}{l}\text { Mg concentration in } \\
\text { sample, } \text { mgL }^{-1}\end{array}$ & $\begin{array}{c}\text { Sample } \\
\text { preparation } \\
\text { method }\end{array}$ & $\begin{array}{c}\text { St. of analyte for } \\
\text { calibration } \\
\text { curve }\end{array}$ & $\begin{array}{c}\text { Adding volume of } 1 \mathrm{M} \\
\mathrm{MgSO}_{4} \text {, for calibration } \\
\text { curve, } \mu \mathrm{L}\end{array}$ \\
\hline $\begin{array}{c}\text { Model Sample } \\
\text { A }\end{array}$ & $\begin{array}{c}96 \\
(0.004 \mathrm{M}) \\
\end{array}$ & reduction & $\mathrm{Fe}(\mathrm{II})$ & 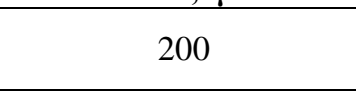 \\
\hline $\begin{array}{c}\text { Model sample } \\
\text { B }\end{array}$ & 96 & $\mathrm{~b}$ & $\mathrm{Fe}(\mathrm{II})$ & 200 \\
\hline \multirow{2}{*}{ C.Ü. tap water } & not known & reduction & $\mathrm{Fe}(\mathrm{II})$ & $180^{c}$ \\
\hline & not known & oxidation & $\mathrm{Fe}(\mathrm{II})$ & $180^{c}$ \\
\hline \multirow{2}{*}{$\begin{array}{c}\text { Beypazarı } \\
\text { mineral water }\end{array}$} & $\begin{array}{c}108.4 \\
\left(4.5 \times 10^{-3} \mathrm{M}\right)\end{array}$ & reduction & $\mathrm{Fe}(\mathrm{II})$ & 225 \\
\hline & $\begin{array}{c}108.4 \\
\left(4.5 \times 10^{-3} \mathrm{M}\right)\end{array}$ & oxidation & $\mathrm{Fe}(\mathrm{III})$ & 225 \\
\hline $\begin{array}{c}\text { Eskipazar } \\
\text { mineral water }\end{array}$ & $\begin{array}{c}126 \\
\left(5.2 \times 10^{-3} \mathrm{M}\right) \\
\end{array}$ & oxidation & $\mathrm{Fe}(\mathrm{III})$ & 260 \\
\hline $\begin{array}{c}\text { Rennie } \\
\text { antiacid tablet }\end{array}$ & $\begin{array}{c}91.4^{\mathrm{a}} \\
\left(3.8 \times 10^{-3} \mathrm{M}\right)\end{array}$ & oxidation & $\mathrm{Fe}(\mathrm{III})$ & 190 \\
\hline \multicolumn{5}{|c|}{$\begin{array}{l}\text { a This value was achieved by solubilizing } 4 \text { tablets in } 1 \mathrm{~L} \\
\text { b No reductant or oxidant are added } \\
\text { c This value is obtained by experimentally }\end{array}$} \\
\hline
\end{tabular}


1) Reduction road: I) About $1 \mathrm{~L}$ of mineral water is taken into a beaker. II) It is wait for a period for the outgassing to complete. $6 \mathrm{M} \mathrm{NaOH}$ is added dropwise to get a $\mathrm{pH} 7$ or slightly above providing no precipitation. III) A tip of spatula (0.1- $0.2 \mathrm{~g}$ ) of solid $\mathrm{Na}_{2} \mathrm{SO}_{3}$ is added and it is mixed for an hour. If alternative reductant is added, it must be followed to above presedure

2) Oxidation road: 1) About $1 \mathrm{~L}$ of mineral water is taken into a large beaker. II) Once the outgassing is complete, add a tip spatula (0.1- 0.2 g) of solid potassium peroxydisulfate $\left(\mathrm{K}_{2} \mathrm{~S}_{2} \mathrm{O}_{8}\right)$ and $2.5 \mathrm{~mL}$ of concentrated $\mathrm{HNO}_{3}$. III) It is left to heat and mixed; it is mixed for an hour without exceeding $40{ }^{\circ} \mathrm{C}$. V) It is cooled to the room temperature.

\subsubsection{Rennie antacid tablet sample preparation}

Oxidation method is employed for this sample. I) 4 tablets (app. $5 \mathrm{~g}$ ) are weighed on the analytical balance with an accuracy of $\pm 0,0001 \mathrm{~g}$. (More than 4 tables for $1 \mathrm{~L}$ causes excessive foaming and the filtering difficulty). II) It is transferred to the $1 \mathrm{~L}$ beaker. $200 \mathrm{~mL}$ double distilled water and 200 $\mathrm{mL} 1 \mathrm{M} \mathrm{HNO}_{3}$ are added gradually. III) A tip of spatula $(0.1-0.2 \mathrm{~g})$ solid potassium peroxydisulfate $\left(\mathrm{K}_{2} \mathrm{~S}_{2} \mathrm{O}_{8}\right)$ is added once the outgassing and foaming are finished. IV) It is heated and mixed; it is mixed at least for an hour without exceeding $40{ }^{\circ} \mathrm{C}$. V) It is cooled down to the room temperature and filtered. The volume is completed to $1 \mathrm{~L}$ by adding water

\section{RESULTS AND DISCUSSIONS}

\subsection{Predicted parameters}

Concentration factor was designed to be 10 (sample volume is $50 \mathrm{~mL}$, final volume is $5 \mathrm{~mL}$ after separation). The final volume, which would be $5 \mathrm{~mL}$, was designed to be as the sum of the following three volumes and agents: 1) $4.00 \mathrm{~mL}$ precipitate dissolvent acid, 2) $100 \mu \mathrm{L}$ saturated $\mathrm{K}_{2} \mathrm{~S}_{2} \mathrm{O}_{8}$ (oxidant), 3) $900 \mu \mathrm{L} \mathrm{KSCN}$ (complexing agent). Pre-addition concentrations of these three reagents were calculated based on the volume parameters given for the spectrophotometric thiocyanate method considered in the literature [3] and appropriate concentrations of these three reagents in the measurement medium. These values are shown in Table 3. Absorpsion peak is observed at $470 \mathrm{~nm}$.

Table 3. Volumes and concentrations of the regeants that will be added to the separated precipitate.

\begin{tabular}{llll}
\hline $\begin{array}{l}\text { Added } \\
\text { reagent }\end{array}$ & $\begin{array}{l}\text { Concentration in the measurement } \\
\text { medium given in the literature }\end{array}$ & Predicted volume & $\begin{array}{l}\text { Calculated } \\
\text { concentration }\end{array}$ \\
\hline $\mathrm{HCl}$ & $0.48 \mathrm{M}$ & $4.00(\mp 0,02) \mathrm{mL}$ & $2 \mathrm{M}^{\mathrm{b}}$ \\
$\mathrm{K}_{2} \mathrm{~S}_{2} \mathrm{O}_{8}$ & $\begin{array}{l}0.5 \mathrm{~mL} \text { doy } / 50 \mathrm{~mL}^{\mathrm{a}} \\
\left(\text { as }\left(\mathrm{NH}_{4}\right)_{2} \mathrm{~S}_{2} \mathrm{O}_{8}\right)\end{array}$ & $100 \mu \mathrm{L}$ & $100 \mu \mathrm{L} \mathrm{doy} / 5 \mathrm{~mL}^{\mathrm{c}}$ \\
$\mathrm{KSCN}$ & $0.33 \mathrm{M}$ & $900 \mu \mathrm{L}$ & $1.83 \mathrm{M}$ \\
\hline
\end{tabular}

a $0.5 \mathrm{~mL}$ satured $\left(\mathrm{NH}_{4}\right)_{2} \mathrm{~S}_{2} \mathrm{O}_{8}$ added in $50 \mathrm{~mL}$ total volume.

b Calculated conc. $0.6 \mathrm{M}$, but $2 \mathrm{M}$ is taken considering that $\mathrm{Mg}(\mathrm{OH})_{2}$ will be solved

c $100 \mu \mathrm{L}$ saturated $\mathrm{K}_{2} \mathrm{~S}_{2} \mathrm{O}_{8}$ is added in $5 \mathrm{~mL}$ total volume

\subsection{Effect of centrifugation time}

In order to find out the proper centrifugation time, centrifugations for different times were performed. 3 repetitive measurement were conducted for each time $(n=3)$. Other conditions and factors are kept as the same for each one. 4 repetitive measurements were carried out for each time, Centrifugation rate at $4000 \mathrm{rpm}$, Measurements were given in Table 4. 
Table 4. Effect of centrifugation time on precipitation (50 $\mathrm{mL}$ of $0.2 \mathrm{ppm} \mathrm{Fe}, 1000 \mu \mathrm{L}$ of $1 \mathrm{M} \mathrm{MgSO}_{4}$ and $500 \mu \mathrm{L}$ of $5 \mathrm{M} \mathrm{NaOH}$ were added to each tube, $\mathrm{n}=4$ ).

\begin{tabular}{cccc}
\hline $\begin{array}{c}\text { Time, } \\
\text { min }\end{array}$ & Absorbance & $\begin{array}{c}\text { Increase in } \\
\text { signal, \% }\end{array}$ & $\begin{array}{c}\text { RSD } \\
(\%)\end{array}$ \\
\hline 10 & 0.318 & - & $<5$ \\
20 & 0.339 & 11.7 & $<5$ \\
30 & 0.351 & 3.5 & $<5$ \\
\hline
\end{tabular}

As seen in Table 4, the signal increases in parallel to the increase in the time. However, this increase becomes insignificant after 20 minutes and lower than the RSD of the measurements. The increase in signal is $11.7 \%$ when the time increases from 10 minutes to 20 minutes. This increase is greater than the RSD \% 5. When the duration increases from 20 minutes to 30 minutes, the increase in absorbance is $3.5 \%$ which is lower than the RSD of signals, $5 \%$. Therefore, 20 minutes is found to be sufficient.

\subsection{Effect of pH}

To a solution containing $50 \mathrm{~mL}$ of $0.1 \mathrm{mgL}^{-1}$ $\mathrm{Fe}(\mathrm{II})$ in a number of tubes, $200 \mu \mathrm{L}$ of $1 \mathrm{M} \mathrm{MgSO}_{4}$ was added. Various amounts of $\mathrm{NaOH}$ solutions were added at various concentrations to obtain media at different pHs. After waiting for 15-20 minutes, they were centrifuged for 20 minutes and then the $\mathrm{pH}$ of each was measured before the supernatant solution was discarded. After the solutions of which $\mathrm{pH}$ values were measured were discarded, each precipitate was dissolved in 4.00 $\mathrm{mL} 2 \mathrm{M} \mathrm{HCl}$ and $100 \mu \mathrm{L}$ of saturated $\mathrm{K}_{2} \mathrm{~S}_{2} \mathrm{O}_{8}$ and $900 \mu \mathrm{L}$ of $\mathrm{KSCN}$ were added. Absorbance readings were taken at $470 \mathrm{~nm}$. Effect of $\mathrm{pH}$ on absorbance was shown in Figure 1.

According to graph in Figure 1, the signal is increasing up to $\mathrm{pH} 10.2$ It remains constant between 10.2 and 12.3. It increases again after 12.3. The optimal $\mathrm{pH}$ range is $11-12$. The optimal $\mathrm{pH}$ is assumed to be 12 rather than the middle of the optimal range (i.e. 11-12) for $\mathrm{Mg}$ to achieve a complete precipitate. At this $\mathrm{pH}$ value, $\mathrm{Ca}(\mathrm{OH})_{2}$ precipitation cannot be observed.

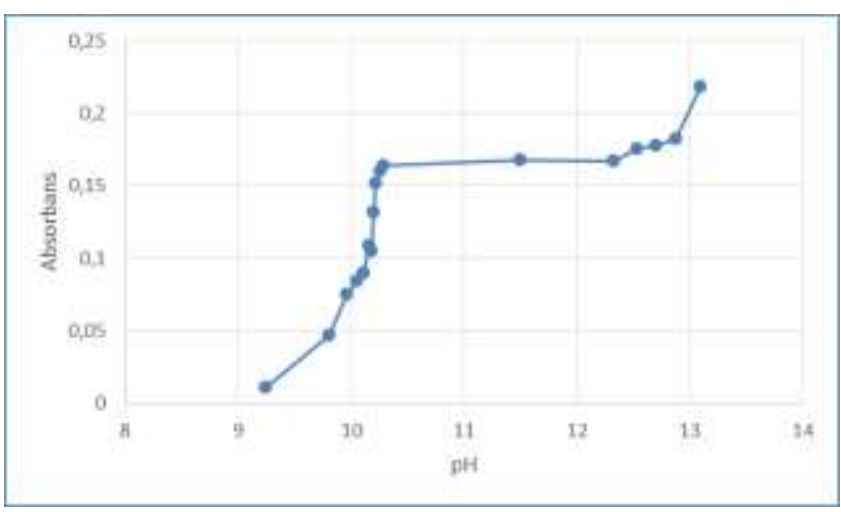

Figure 1. Effect of $\mathrm{pH}$ on absorbance (Medium: $0.1 \mathrm{mgL}^{-1}$ $\mathrm{Fe}(\mathrm{II}) \mathrm{st}, 4 \times 10^{-3} \mathrm{M} \mathrm{Mg}(\mathrm{II})$.

\subsection{Effect of $\mathrm{Mg}^{2+}$ concentration}

It was done also parallel adding of each adding. $500 \mu \mathrm{L}$ of $10 \mathrm{ppm} \mathrm{Fe}^{2+}$ was added in each tube and the concentration of $\mathrm{Fe}$ (II) was set to $0.1 \mathrm{mgL}^{-}$ ${ }^{1}$ by completing the volumes to $50 \mathrm{~mL}$ adding water. Following this, $1000 \mu \mathrm{L}$ of $1 \mathrm{M} \mathrm{MgSO}_{4}$ was added to the reference and between 100-1000 $\mu \mathrm{L}$ of $1 \mathrm{M} \mathrm{MgSO}_{4}$ added to the others. Then, 700 $\mu \mathrm{L}$ of $6 \mathrm{M} \mathrm{NaOH}$ was added. Then, It was waited for 15-20 minutes and centrifuged for 20 minutes. After centrifugation and supernatant solution discarding the same operations as in Section 2.2 are applied. Plotting the absorbance against $\mathrm{Mg}$ reactivate volume has provided Figure 2. 


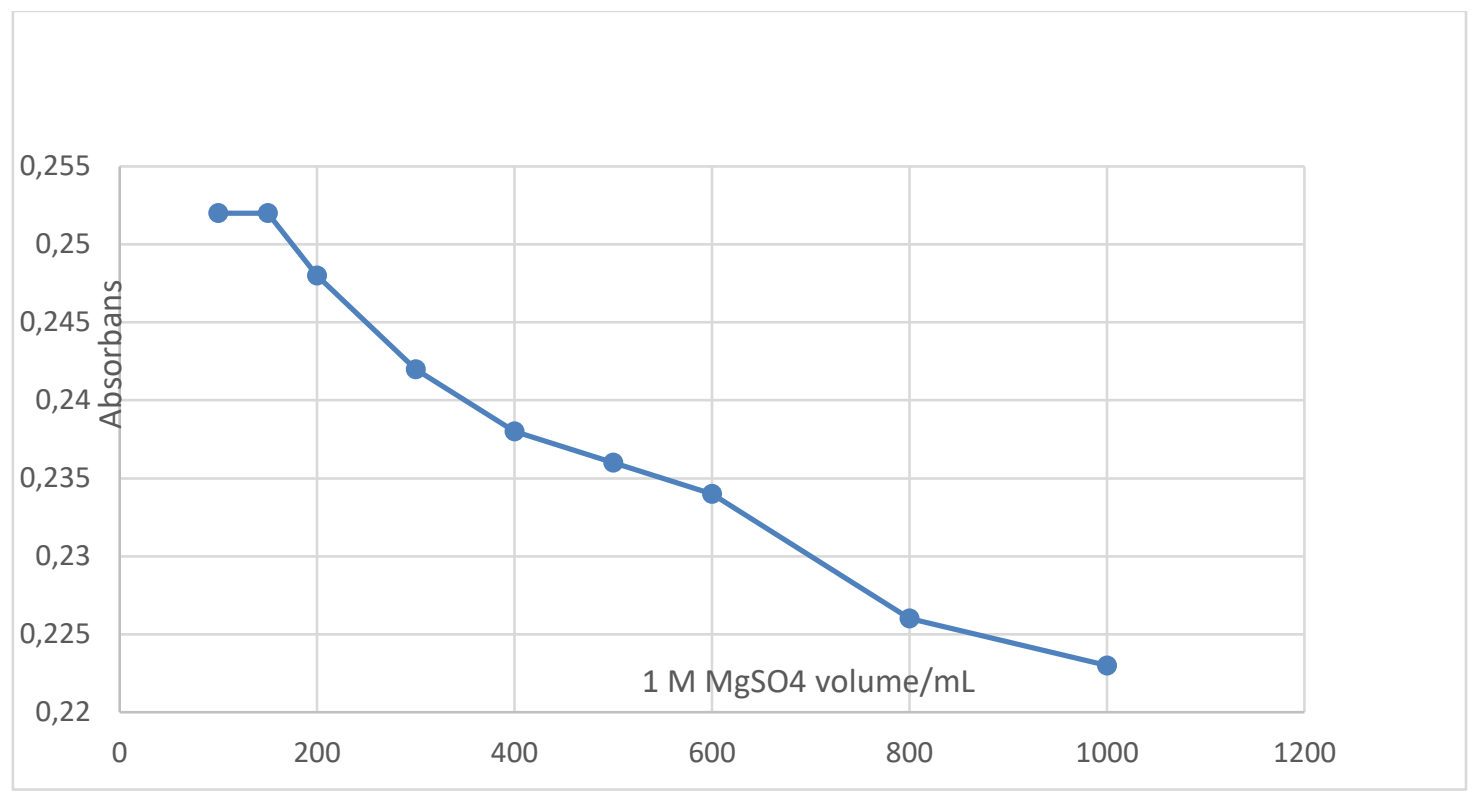

Figure 2. The effect of added $1 \mathrm{M} \mathrm{MgSO}_{4}$ volume. (Medium: $50 \mathrm{~mL}$ of $0.1 \mathrm{mgL}^{-1} \mathrm{Fe}(\mathrm{II})$ and $700 \mu \mathrm{L}$ of $6 \mathrm{M}$ NaOH solution were added to each tube.

According to the Figure 2, the signal reduces with increasing $\mathrm{Mg}$ concentration. However, this reduction is insignificant and the difference between the maximum and minimum absorbances is not more than 0.030 (close to the blank test signal). The optimal value was accepted to be 200 $\mu \mathrm{L}$. However, this value is taken only to be added to the calibration curve standards that would be prepared for the analysis of water samples with the unknown $\mathrm{Mg}$ concentrations. If $\mathrm{Mg}$ is present in the sample and its concentration is specified on the label or prospectus, $\mathrm{Mg}$ of sample is used as a collector. For these kinds of samples, $\mathrm{Mg}$ reagent with equivalent concentration to that of in the sample is added to the standards of calibration curves. Whether its concentration is known or not, $\mathrm{MgSO}_{4}$ is not added to a sample which contains $\mathrm{Mg}$. Mg of samples is used as collector.

\section{3 .5 Interferences}

When investigating the interference of heavy metal ions, a grouping was made as: Amphoter ones and not amphoter ones. Any interfences cannot be expected for amphoter ones because they would be polyatomic and anionically ionized in the alkaline precipitation medium of the method. Only, investigation of $\mathrm{Cr}(\mathrm{VI})$ interfence from this group was considered to be sufficient. For not amphoter ones, trace toxic metals that can be present in water, that are, $\mathrm{Cd}(\mathrm{II}), \mathrm{Co}(\mathrm{II})$, $\mathrm{Cu}$ (II), $\mathrm{Cr}$ (III), $\mathrm{Hg}$ (II), $\mathrm{Mn}$ (II), Ni(II) and, the interference of $\mathrm{KF}$ ve $\mathrm{NaHCO}_{3}$ species were investigated. For this purpose, different volumes of solution standards of which interference to be studied were added to the tubes. Then $50 \mathrm{~mL}$ of $0.2 \mathrm{mgL}^{-1} \mathrm{Fe}$ (II) standard solution, $200 \mu \mathrm{L}$ of 1 $\mathrm{M} \mathrm{MgSO}_{4}$ solution and $600 \mu \mathrm{L}$ of $6 \mathrm{M} \mathrm{NaOH}$ solution was added to each tube. Then, the known procedures were applied. The results are given in Table 5. The tolerance limit (tolerable limit) was taken as the interfrent concentration or the corresponding interfrent / analyte ratio, which changed the absorbance by $\mp 5 \%$. 
Table 5. Tolerance limits of some ions. Medium: $50 \mathrm{~mL}$ of $0.2 \mathrm{mgL}^{-1} \mathrm{Fe}(\mathrm{II}), 200 \mu \mathrm{L}$ of $1 \mathrm{M} \mathrm{MgSO}_{4}$ and $600 \mu \mathrm{L}$ of $6 \mathrm{M} \mathrm{NaOH}$ solution were added to each tube. $(\mathrm{n}=3)$.

\begin{tabular}{cccccc}
\hline $\begin{array}{c}\text { Species } \\
(\mathbf{S p})\end{array}$ & $\begin{array}{c}{[\mathbf{S p}] /[\mathbf{F e}]} \\
\mathbf{p p m} / \mathbf{p p m}\end{array}$ & $\begin{array}{c}\text { Tolerable } \\
\text { limit, } \mathbf{~ m L L}^{-\mathbf{1}}\end{array}$ & $\begin{array}{c}\text { Species } \\
(\mathbf{S p})\end{array}$ & $\begin{array}{c}{[\mathbf{S p}] /[\mathbf{F e}]} \\
\mathbf{p p m} / \mathbf{p p m}\end{array}$ & $\begin{array}{c}\text { Tolerable } \\
\text { limit, } \mathbf{~ m L L}^{-\mathbf{1}}\end{array}$ \\
\hline $\mathrm{CaCl} 2$ & 11400 & 2280 & $\mathrm{Hg}(\mathrm{II})$ & 230 & 46 \\
$\mathrm{Cd}(\mathrm{II})$ & $>300$ & $>60$ & $\mathrm{Mn}(\mathrm{II})$ & $>1000$ & $>200$ \\
$\mathrm{Co}(\mathrm{II})$ & 15 & 3 & $\mathrm{Ni}(\mathrm{II})$ & $>200$ & $>40$ \\
$\mathrm{Cr}(\mathrm{III})$ & 20 & 4 & $\mathrm{KF}$ & $>750$ & $>150$ \\
$\mathrm{Cr}(\mathrm{VI})$ & 100 & 20 & $\mathrm{NaHCO}_{3}$ & $>2050$ & $>410$ \\
$\mathrm{Cu}(\mathrm{II})$ & 1.2 & 0.24 & & & \\
\hline
\end{tabular}

Table 6. Parameters of the calibration curves for the proposed determination method (with concentration) and the determination method without concentration (for with preconcentration method to each tube: Fe st added was dilueted to $50 \mathrm{~mL}$, Table 2 was followed for the values be added of $1 \mathrm{M} \mathrm{MgSO}_{4}$. $\mathrm{pH}$ was set to 12, centrifugation rate $4000 \mathrm{rpm}$, centrifugation time 20 min., 4.00

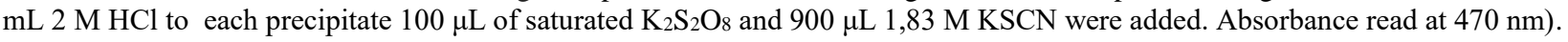

\begin{tabular}{|c|c|c|c|}
\hline \multirow[t]{2}{*}{ Parameter type } & \multirow[t]{2}{*}{$\begin{array}{l}\text { The method without } \\
\text { preconcentration }\end{array}$} & \multicolumn{2}{|c|}{$\begin{array}{l}\text { The method with preconcentration } \\
\text { (The proposed method) }\end{array}$} \\
\hline & & According to $\mathrm{Fe}(\mathrm{II})$ & According to $\mathrm{Fe}(\mathrm{III})$ \\
\hline $\begin{array}{l}\text { Linear regression } \\
\text { equation }\end{array}$ & $\begin{aligned} \mathrm{A}= & 0.151 \mathrm{c}+0.007 \\
& \left(\mathrm{c}: \mathrm{mgL}^{-1}\right)\end{aligned}$ & $\mathrm{A}=1.802 \mathrm{c}+0.024$ & $\mathrm{~A}=1.866 \mathrm{c}+0.042$ \\
\hline Corelation constant/ $\mathrm{r}^{2}$ & 0.998 & 0.999 & 0.998 \\
\hline $\begin{array}{c}\text { Measurement/peak } \\
\text { wavelength } / \lambda_{\text {maks }}(\mathrm{nm})\end{array}$ & 470 & 470 & 470 \\
\hline $\begin{array}{c}\text { molar absorption } \\
\text { coefficient } \\
\left(\mathrm{Lmol}^{-1} \mathrm{~cm}^{-1}\right)\end{array}$ & $8.4 \times 10^{3}$ & $1.0 \times 10^{5}$ & $1.1 \times 10^{5}$ \\
\hline $\begin{array}{l}\text { Sandell`s sensitivity } \\
\left(\mathrm{ng} / \mathrm{cm}^{2}\right)\end{array}$ & 6.6 & 0.63 & 0.57 \\
\hline $\begin{array}{c}\text { Dedection limit } \\
3 \mathrm{~s} / \mathrm{m}\left(\mathrm{mgL}^{-1}\right)\end{array}$ & 0.12 & 0.01 & 0.01 \\
\hline $\begin{array}{c}10 \mathrm{~s} / \mathrm{m}\left(\mathrm{mgL}^{-1}\right) \\
\text { quantization limit }\end{array}$ & 0.4 & 0.03 & 0.03 \\
\hline $\begin{array}{l}\text { working interval } \\
\left(\mathrm{mgL}^{-1}\right)\end{array}$ & $0.4-20$ & $0.03-0.30$ & $0.03-0.30$ \\
\hline $\begin{array}{l}\text { Concentration factor }^{\mathrm{b}} \\
\text { (or preconc. factor) }\end{array}$ & - & 10 & 10 \\
\hline Improvement factor ${ }^{\mathrm{c}}$ & - & 11.9 & 12.3 \\
\hline \multicolumn{4}{|c|}{$\begin{array}{l}\text { a Concentration rise which causes to an increase of } 0.001 \text { in absorbance in a spectrophotometer with } 1 \mathrm{~cm} \\
\text { beam length [4] } \\
\mathrm{b} \text { The ratio of sample volume preperated before separation to the sample volume after separation } \\
\mathrm{c} \text { The ratio of the LR equation slope of the proposed method to the LR slope of the method without } \\
\text { preconcentration }\end{array}$} \\
\hline
\end{tabular}

\subsection{Calibration curve parameters}

By applying the optimal values obtained above, the calibration curve and related parameters were obtained. Differently, Table 2 was followed for the volume value be added of $1 \mathrm{M} \mathrm{MgSO}_{4}$. The parameters of the calibration curves for the with preconcentration method (proposed method) and without preconcentration method are shown in Table 6.

The slop of the linear regressions equations obtained through the proposed method is ten times more than that of the other method without 
preconcentration (see Table 6). Thus, the calibration sensitivity is increased at least ten times in the proposed method.

\subsection{Appicability of the method}

The accuracy of the presented method was tested on model the samples by direct comparison and on the real samples by analyte spiked methods. The sample compositions are given on Table 1. The comparison results on the model sample are given in Table 7 . The findings obtained from the analyte spiked method on the real samples are presented in Table 8 .

From Table 7, Table 8 and Table 9, it is obvious that most of the RSD values are in the acceptable range while only a few are above 5\%. These RSD figures are sufficient to prove the precision of the proposed method. In terms of the validness, most recovery \% values are above $90 \%$ supporting the accurty of the proposed method.

Table 7. Application of the proposed methods on model samples $(50 \mathrm{~mL}$ of sample was added to each tube. The $\mathrm{MgSO}_{4}$ solution was not added to this sample or to any samples. The $\mathrm{pH}$ adjustment and subsequent operations are as in Table 6.

\begin{tabular}{|c|c|c|c|c|c|}
\hline Sample & $\begin{array}{c}\text { Known Fe } \\
\text { conc., } \\
\text { mgL }^{-1}\end{array}$ & $\begin{array}{c}\text { Found } \\
\text { value, } \text { mgL }^{-1} \\
\bar{x} \pm t s / \sqrt{n} *\end{array}$ & $\begin{array}{l}\text { Recovery } \\
(\%)\end{array}$ & $\begin{array}{c}\text { Relative st. } \\
\text { deviation } \\
(\text { RSD\%) }\end{array}$ & $\begin{array}{l}\text { Sample preparation } \\
\text { method/conversion }\end{array}$ \\
\hline $\begin{array}{l}\text { Model } \\
\text { sample A }\end{array}$ & 0.20 & $0.203 \pm 0.010$ & 101 & 1.9 & $\begin{array}{l}\text { Reduction ( } 100 \mu \mathrm{L} \text { of } 2 \% \mathrm{Na}_{2} \mathrm{SO}_{3} \\
\text { was added to each tube) }\end{array}$ \\
\hline $\begin{array}{l}\text { Model } \\
\text { sample B }\end{array}$ & 0.20 & $0.206 \pm 0.003$ & 103 & 1.7 & No reductant or oxidant was added \\
\hline
\end{tabular}

Table 8. Application of the proposed methods on water samples by conversion into Fe(II) and testing its accuracy by the analyte spiked method. After sample and iron standards additions, other operations that continue with $\mathrm{pH}$ adjustment are as in Table 6.

\begin{tabular}{|c|c|c|c|c|c|}
\hline Sample & $\begin{array}{c}\text { Added conc., } \\
\text { mgL }^{-1}\end{array}$ & $\begin{array}{c}\text { Found value, } \\
\text { mgL }^{-1} \\
\bar{x} \pm t s / \sqrt{n} *\end{array}$ & $\begin{array}{l}\text { Rec. } \\
(\%)\end{array}$ & $\begin{array}{l}\text { RSD } \\
(\%)\end{array}$ & Sample preperation method/ conversion \\
\hline \multirow{5}{*}{$\begin{array}{l}\text { C.U. } \\
\text { tap water }\end{array}$} & 0 & $0.030 \pm 0.005$ & - & 6.3 & \multirow{5}{*}{$\begin{array}{l}\text { Reduction } \\
\text { (by adding solid } \mathrm{Na}_{2} \mathrm{SO}_{3} \text { ) }\end{array}$} \\
\hline & 0.04 & $0.070 \pm 0.003$ & 101 & 1.8 & \\
\hline & 0.08 & $0.107 \pm 0.010$ & 96 & 0.4 & \\
\hline & 0.12 & $0.146 \pm 0.008$ & 96 & 2.2 & \\
\hline & 0.16 & $0.183 \pm 0.006$ & 96 & 1.4 & \\
\hline \multirow{4}{*}{$\begin{array}{l}\text { C.U. } \\
\text { tap water }\end{array}$} & 0 & $0.016 \pm 0.004$ & - & 10 & \multirow{4}{*}{$\begin{array}{l}\text { Reduction } \\
\text { (by adding } 100 \mu \mathrm{L} 2 \% \mathrm{Na}_{2} \mathrm{SO}_{3} \text { to each tube) }\end{array}$} \\
\hline & 0.04 & $0.052 \pm 0.003$ & 91 & 1.9 & \\
\hline & 0.08 & $0.093 \pm 0.004$ & 97 & 2.0 & \\
\hline & 0.12 & $0.132 \pm 0.006$ & 97 & 2.0 & \\
\hline \multirow{4}{*}{$\begin{array}{l}\text { Beypazari } \\
\text { mineral water }\end{array}$} & 0 & $0.006 \pm 0.004$ & - & 25 & \multirow{4}{*}{$\begin{array}{l}\text { Reduction } \\
\text { (by adding } 100 \mu \mathrm{L} 2 \% \mathrm{Na}_{2} \mathrm{SO}_{3} \text { to each tube) }\end{array}$} \\
\hline & 0.04 & $0.041 \pm 0.002$ & 94 & 1.5 & \\
\hline & 0.08 & $0.075 \pm 0.004$ & 87 & 1.9 & \\
\hline & 0.16 & $0.149 \pm 0.006$ & 90 & 1.5 & \\
\hline
\end{tabular}

* \%95 confidence level, $\mathrm{n}=3, \mathrm{t}=4.30, \bar{x}:$ Mean values 
There is a relation between sample preparation method with accuracy for water samples. Higher accuracy was achieved by reduction for water samples. Oxydation method was preferred for antiacid tablet because sample preparation for antiacid tablet is necessarily initiated with acid addition. Further, the oxidation method which is compatible with this medium requires less work. In the reduction method, solid $\mathrm{Na}_{2} \mathrm{SO}_{3}$ and $2 \%$ $\mathrm{Na}_{2} \mathrm{SO}_{3}$, which can substitute each other as a reductor, produced results with closed accuracy.

Table 9. Application of the proposed methods on water and antiacid tablet samples by conversion to Fe(III) and testing its accuracy by analyte spiked method. After sample and iron standards additions, other operations that continue with pH adjustment are as in Table 6.

\begin{tabular}{|c|c|c|c|c|c|}
\hline Sample species & $\begin{array}{l}\text { Added } \\
\text { conc., } \\
\text { mgL }^{-1}\end{array}$ & $\begin{array}{c}\text { Found volue, } \\
\text { mgL }^{-1} \\
\bar{x} \pm t s / \sqrt{n} *\end{array}$ & $\begin{array}{c}\text { Recovery } \\
(\%)\end{array}$ & $\begin{array}{l}\text { RSD } \\
(\%)\end{array}$ & $\begin{array}{l}\text { Sample preperation } \\
\text { method / conv. }\end{array}$ \\
\hline \multirow{5}{*}{$\begin{array}{l}\text { C.U. } \\
\text { tap water }\end{array}$} & 0 & $0.010 \pm 0.001$ & - & 3.0 & \multirow{20}{*}{$\begin{array}{l}\text { Oxidation (conversiyon to } \\
\mathrm{Fe}(\mathrm{III}) \text { by adding solid } \\
\left.\mathrm{K}_{2} \mathrm{~S}_{2} \mathrm{O}_{8}\right)\end{array}$} \\
\hline & 0.04 & $0.045 \pm 0.0002$ & 87 & 0.2 & \\
\hline & 0.08 & $0.077 \pm 0.004$ & 83 & 2.0 & \\
\hline & 0.12 & $0.107 \pm 0.002$ & 80 & 1.0 & \\
\hline & 0.16 & $0.134 \pm 0.004$ & 77 & 5.8 & \\
\hline \multirow{5}{*}{$\begin{array}{l}\text { Beypazari } \\
\text { mineral water }\end{array}$} & 0 & $0.012 \pm 0.016$ & - & 53 & \\
\hline & 0.04 & $0,048 \pm 0.004$ & 89 & 3.4 & \\
\hline & 0.08 & $0.083 \pm 0.006$ & 89 & 3.1 & \\
\hline & 0.12 & $0.116 \pm 0.005$ & 87 & 1.6 & \\
\hline & 0.16 & $0.159 \pm 0.011$ & 92 & 2.8 & \\
\hline \multirow{5}{*}{$\begin{array}{l}\text { Eskipazar } \\
\text { mineral water }\end{array}$} & 0 & $0.011 \pm 0.001$ & - & 5.2 & \\
\hline & 0.04 & $0.046 \pm 0.014$ & 88 & 12.2 & \\
\hline & 0.08 & $0.078 \pm 0.004$ & 85 & 2.2 & \\
\hline & 0.12 & $0.115 \pm 0.014$ & 88 & 4.9 & \\
\hline & 0.16 & $0.155 \pm 0.049$ & 90 & 13 & \\
\hline \multirow{5}{*}{$\begin{array}{l}\text { Rennie } \\
\text { antiacid tablet }\end{array}$} & 0 & $0.241 \pm 0.084$ & - & 1.6 & \\
\hline & 0.04 & $0.296 \pm 0.014$ & 136 & 2.0 & \\
\hline & 0.08 & $0.312 \pm 0.057$ & 89 & 7.3 & \\
\hline & 0.12 & $0.338 \pm 0.013$ & 81 & 1.6 & \\
\hline & 0.16 & $0.379 \pm 0.049$ & 86 & 5.2 & \\
\hline
\end{tabular}

\subsection{Compare the same field with other methods}

The detection limit of the proposed method is larger than that of most of the methods given in Table 10. There are two reasons for this; 1) Instrument 2) Preconcentration factor. The analytical instrument UV-VIS absorption spectrophotometer used in the proposed method is not used by any of the methods given in Table 10 . As seen Table 10, there are 23 studies of which 15 used FAAS, 5 used ICP-AES and 4 used ICPMS. The detection limits of these istrument are lower than that of an UV-VIS spectrophotometer; that is, they are more sensitive. 
Table 10. Studies into the preconcentration of iron by coprecipitation between 1997 and 2015 in literature

\begin{tabular}{|c|c|c|c|c|c|c|}
\hline Analytes & Collector & $\begin{array}{l}\text { Fe detection } \\
\text { limit, } \mu \mathrm{gL}^{-1}\end{array}$ & $\mathbf{C F}^{\mathrm{a}}$ & $\begin{array}{l}\text { Instru- } \\
\text { ment }\end{array}$ & Sample & Reference \\
\hline $\begin{array}{l}\mathrm{Cu}, \mathbf{F e}, \mathrm{Pb}, \mathrm{Mn}, \\
\mathrm{Zn}, \mathrm{Cd}, \mathrm{Ni}, \mathrm{Bi}, \mathrm{Cr}\end{array}$ & Co-DDTC & 54 & $75-225$ & FAAS & $\begin{array}{l}\text { Dialysis samples, sea } \\
\text { water }\end{array}$ & [5] \\
\hline $\mathbf{F e}$ & $\mathrm{Mg}(\mathrm{OH})_{2}$ & 0.003 & 14 & ICPMS & Sea water & [6] \\
\hline $\begin{array}{l}\mathrm{Se}, \mathrm{Cu}, \mathrm{Pb}, \mathrm{Zn}, \\
\text { Fe Co, Ni, Mn, } \\
\mathrm{Cr}, \mathrm{Cd}\end{array}$ & Co-DDTC & 4 & 40 & ICP-AES & $\begin{array}{l}\text { River and waste } \\
\text { water samples }\end{array}$ & [7] \\
\hline $\begin{array}{l}\mathbf{F e}(\mathbf{I I}), \mathrm{Fe}(\mathbf{I I I}), \\
\mathrm{Pb}\end{array}$ & $\mathrm{LaPO}_{4}$ & $\mathrm{~b}$ & 10 & ICP-AES & Water samples & [8] \\
\hline $\begin{array}{l}\mathrm{Al}, \mathrm{Au}, \mathrm{Bi}, \mathrm{Cd}, \\
\mathrm{Co}, \mathrm{Cu}, \mathrm{Fe}, \mathrm{Mo}, \\
\mathrm{Ni}, \mathrm{Pb}, \mathrm{Pd} \mathrm{Ti}, \mathrm{V}, \\
\mathrm{W}, \mathrm{Zn}\end{array}$ & $\mathrm{MnO}_{2}$ & 5 & 80 & $\begin{array}{l}\text { FAAS } \\
\text { ICP- } \\
\text { AES }\end{array}$ & $\begin{array}{l}\text { Natural water } \\
\text { samples }\end{array}$ & [9] \\
\hline $\begin{array}{l}\mathrm{Cu}(\mathrm{II}), \mathbf{F e}(\mathrm{II}), \\
\mathrm{Cd}(\mathrm{II}), \mathrm{Pb}(\mathrm{II}), \\
\mathrm{Co}(\mathrm{II}), \mathrm{Ni}(\mathrm{II})\end{array}$ & $\begin{array}{l}\mathrm{Zn-} \\
\text { HMDTC- } \\
\text { HMA }\end{array}$ & 36.1 & $25-500$ & FAAS & $\begin{array}{l}\text { Waste water, certified } \\
\text { cediment and zinko } \\
\text { samples }\end{array}$ & [10] \\
\hline $\mathrm{Co}, \mathrm{Cr}, \mathrm{Pb}, \mathbf{F e}$ & $\mathrm{Er}(\mathrm{OH})_{3}$ & 0.67 & 25 & FAAS & $\begin{array}{l}\text { Soil, urine, sediment, } \\
\text { and natural water } \\
\text { samples }\end{array}$ & [11] \\
\hline $\mathbf{F e}(\mathbf{I I I}), \mathrm{Pb}, \mathrm{Bi}$ & $\mathrm{YPO}_{4}$ & 0.08 & 20 & ICP-AES & $\begin{array}{l}\text { Metal and } \mathrm{Cl}^{-} \text {salt } \\
\text { solutions of } \mathrm{Co}^{2+} \text {, } \\
\mathrm{Ni}^{2+} \mathrm{Cu}^{2+}\end{array}$ & [12] \\
\hline $\begin{array}{l}\mathrm{Cr}(\mathrm{III}), \mathbf{F e I I I} \\
\mathrm{Pb}(\mathrm{II}), \mathrm{Mn}(\mathrm{II})\end{array}$ & $\mathrm{Eu}(\mathrm{OH})_{3}$ & 7.2 & 500 & FAAS & $\begin{array}{l}\text { Food, fertilizer, } \\
\text { soil and water } \\
\text { samples }\end{array}$ & {$[13]$} \\
\hline $\begin{array}{l}\mathrm{Pb}(\mathrm{II}), \mathrm{Fe}(\mathrm{III}), \\
\mathrm{Cd}(\mathrm{II}), \mathrm{Au}(\mathrm{III}), \\
\mathrm{Pd}(\mathrm{II}), \mathrm{Ni}(\mathrm{II})\end{array}$ & $\begin{array}{l}\mathrm{Cu}-\mathrm{II} \\
\text { rubeanic } \\
\text { acid }\end{array}$ & 0.14 & $12.5-2.5$ & FAAS & $\begin{array}{l}\text { Water, soil, and } \\
\text { sediment samples }\end{array}$ & {$[14]$} \\
\hline $\mathrm{Pb}(\mathrm{II}), \mathbf{F e}(\mathbf{I I I})$ & $\begin{array}{l}\text { Violiric } \\
\text { acid-Cu II }\end{array}$ & 0.18 & $50-100$ & FAAS & $\begin{array}{l}\text { Sea and mineral } \\
\text { waters, urine, soil and } \\
\text { physiological } \\
\text { solution }\end{array}$ & {$[15]$} \\
\hline Fe, $\mathrm{Mn}, \mathrm{Co}$ & $\mathrm{Mg}(\mathrm{OH})_{2}$ & - & 26 & ICPMS & ocean water & {$[16]$} \\
\hline $\begin{array}{l}\mathbf{F e}(\text { III) and nine } \\
\text { element ion }\end{array}$ & $\begin{array}{l}\text { Cu-II-9- } \\
\text { fenil-3- } \\
\text { floron } \\
\end{array}$ & 12.9 & 30 & $\begin{array}{l}\text { FAAS } \\
\text { ICPMS }\end{array}$ & Water, sediment & {$[17]$} \\
\hline $\begin{array}{l}\mathrm{Cr}(\mathrm{III}), \mathbf{F e}(\mathrm{III}), \\
\mathrm{Pb}(\mathrm{II}), \mathrm{Zn}(\mathrm{II})\end{array}$ & $\begin{array}{l}\text { POHBAT } \\
\text { free carrier } \\
\text { element }\end{array}$ & 0.7 & 10 & FAAS & $\begin{array}{l}\text { Environmental } \\
\text { sample }\end{array}$ & {$[18]$} \\
\hline
\end{tabular}


Continued in Table 10

\begin{tabular}{|c|c|c|c|c|c|c|}
\hline Analytes & Collector & $\begin{array}{l}\text { Fe detection } \\
\text { limit, } \mu \mathrm{gL}^{-1}\end{array}$ & $\mathbf{C F}^{*}$ & Instrument & Sample & Reference \\
\hline $\begin{array}{l}\mathbf{F e} \text { and twenty- } \\
\text { six elements }\end{array}$ & $\mathrm{InPO}_{4}$ & 0,20 & $10-30$ & ICP-AES & Commercial salt & [19] \\
\hline $\begin{array}{l}\mathbf{F e}(\mathbf{I I I}), \mathrm{Pb}, \\
\mathrm{Cu}(\mathrm{II})\end{array}$ & $\begin{array}{l}\text { Cu-II- } \\
\text { salisildoxim, } \\
\text { Ni-II- } \\
\text { salisildoxim } \\
\end{array}$ & 1.6 & 20 & FAAS & Water samples & {$[20]$} \\
\hline $\begin{array}{l}\mathrm{Pb}, \mathrm{Co}, \mathrm{Cu}, \mathrm{Cd}, \\
\mathrm{Fe}, \mathrm{Ni}\end{array}$ & $\mathrm{Zr}(\mathrm{OH})_{4}$ & 1.53 & 25 & FAAS & $\begin{array}{l}\text { Natural water, tea, } \\
\text { coffee, tabocca } \\
\text { and fish samples }\end{array}$ & {$[21]$} \\
\hline $\mathbf{F e}$ & $\mathrm{Mg}(\mathrm{OH})_{2}$ & 0.005 & 10 & ICP-MS & Ocean water & [22] \\
\hline $\begin{array}{l}\mathrm{Cd}(\mathrm{II}), \mathrm{Cr}(\mathrm{III}) \\
\mathrm{CoII}, \mathrm{Cu}(\mathrm{II}), \\
\mathbf{F e}(\mathrm{III}), \mathrm{Pb}(\mathrm{II}), \\
\mathrm{Mn}(\mathrm{II})\end{array}$ & $\begin{array}{l}\text { CTAB } \\
\text { free carrier } \\
\text { element }\end{array}$ & 2.1 & 10 & FAAS & $\begin{array}{l}\text { Natural water and } \\
\text { soil samples }\end{array}$ & [23] \\
\hline $\begin{array}{l}\mathrm{Co}, \mathrm{Pb}, \mathrm{Cu}, \mathbf{F e} \\
\text { ve } \mathrm{Zn}\end{array}$ & $\begin{array}{l}\text { Ni(II)-2- } \\
\text { nitroso-1- } \\
\text { naftol-4- } \\
\text { sülfonic acid }\end{array}$ & 1.38 & 25 & FAAS & $\begin{array}{l}\text { Environmental } \\
\text { sample }\end{array}$ & {$[24]$} \\
\hline $\begin{array}{l}\mathrm{Pb}(\mathrm{II}), \mathbf{F e} \text { III, } \\
\mathrm{CoII}, \mathrm{Cr}(\mathrm{III}), \\
\mathrm{Zn}\end{array}$ & Cu-BPHA & 2.3 & 150 & FAAS & $\begin{array}{l}\text { Natural water, hair, } \\
\text { urine, soil, sediment } \\
\text { and peritoneal } \\
\text { fluids samples }\end{array}$ & {$[25]$} \\
\hline $\begin{array}{l}\mathrm{Cu}(\mathrm{II}), \mathrm{Co}(\mathrm{II}), \\
\mathrm{Cd}(\mathrm{II}), \mathrm{Ni}(\mathrm{II}), \\
\mathrm{Mn}(\mathrm{II}), \text { FeIII, } \\
\mathrm{Pb}(\mathrm{II}),\end{array}$ & $\begin{array}{l}\mathrm{Tm}(\mathrm{OH})_{\mathrm{x}} \\
\text { (Tulyum } \\
\text { hidroksit) }\end{array}$ & 0.50 & 120 & FAAS & $\begin{array}{l}\text { Food and } \\
\text { environmental } \\
\text { samples }\end{array}$ & {$[26]$} \\
\hline $\begin{array}{l}\text { FeIII, Cr(III), } \\
\mathrm{Co}(\mathrm{II}), \mathrm{Pb}(\mathrm{II}), \\
\mathrm{Zn}(\mathrm{II})\end{array}$ & $\mathrm{Cu}(\mathrm{II})-\mathrm{BPHA}$ & 0.67 & 100 & FAAS & Food samples & {$[27]$} \\
\hline $\begin{array}{l}\mathrm{Cu}(\mathrm{II}), \mathrm{Pb}(\mathrm{II}), \\
\mathrm{Zn}(\mathrm{II}), \mathbf{F e I I I}, \\
\mathrm{Cr}(\mathrm{III})\end{array}$ & $\begin{array}{l}\mathrm{BCP} \\
\text { (free carrier } \\
\text { element) }\end{array}$ & 0.91 & 25 & FAAS & $\begin{array}{l}\text { Water and food } \\
\text { samples }\end{array}$ & [28] \\
\hline $\mathbf{F e}$ & $\operatorname{Mg}(\mathrm{OH})_{2}$ & 10 & 10 & $\begin{array}{l}\text { UV-VIS } \\
\text { Spek. }\end{array}$ & $\begin{array}{l}\text { Tab water, } \\
\text { mineral water, } \\
\text { Rennie antiacid } \\
\text { tablet }\end{array}$ & This work \\
\hline
\end{tabular}

There are some istrument like ICP-AES which can determine a concentration value with no need for preconcentrating while preconcentrating is essential to be determined by using an UV-VIS spectrophotometer. Another factor which affects the sensitivity is preconcentration factor. The preconcentration factor of the proposed method is
10. This value is the same with 10 of the studies in Table 3.8 while it is lower than the others. While it is possible to increase this value by reducing the final volume below $5 \mathrm{~mL}$ in the AAS, it is difficult in in the UV-VIS spectrophotometer. 


\section{CONCLUSION}

The proposed method can be applied to tap water, mineral water, and antiacid tablets. This method can also be recommended for other water samples with metal pollution in which the copper concentration is not higher than that of the iron. High-grade interference in $\mathrm{Cu}$ (II) is not observed in atomic spectrometric methods such as AAS and AES. However, the hardware cost of these devices is about five times that of an UV-VIS spectrophotometre and may not be available in most analytical laboratories. The proposed method can be employed by the corporations/institutions with shoestring budgets that cannot afford to purchase such analytical devices more expensive than an UV-VIS spectrophotometer.

\section{Acknowledgements}

We thank the Cumhuriyet University Scientific Research Projects (CÜBAP) Commission for supporting this work as F-390.

\section{REFERENCES}

[1]. Minczewski J., Chwastowska J., Dybczynski J., Seperation and Preconcentration Methods in Inorganic Trace Analysis, Ellis Horwood Chichester, 1982 pp 39-56,

[2]. Okochi H., Sudo E. Separation of micro quantities of bismuth and iron in lead by EDTA masking-coprecipitation method, Bunseki Kagaku, 22-4 (1973) 431-437 NKI.

[3]. K Kitson, R.E., Smultaneous Spectrophotometric Determination of Cobalt, Copper and Iron, Analytical Chemistry, 22-5 (1950) 664.

[4]. Bode, H., On Sandell's sensivity, Fresenius J Anal Chem., 339 (1991) 898.

[5]. Elçi L., Şahin U., Öztaş S., Determination of trace amounts of some metals in samples with high salt content by atomic absorption spectrometry after cobaltdiethyldithiocarbamate coprecipitation, Talanta, 44 (1997) 1017-1023.

[6]. Wu J., Boyle E. A., Determination of iron in seawater by high-resolution isotope dilution inductively coupled plasma mass spectrometry after $\mathrm{Mg}(\mathrm{OH})_{2}$ coprecipitation, Analytica Chimica Acta, 367 (1998) 183-191.

[7]. Ata Atanassova D., Stefanova V., Russeva E., Co-precipitative preconcentration with sodium diethyldithiocarbamate and ICP-AES determination of $\mathrm{Se}, \mathrm{Cu}, \mathrm{Pb}, \mathrm{Zn}, \mathrm{Fe}, \mathrm{Co}$, $\mathrm{Ni}, \mathrm{Mn}, \mathrm{Cr}$ and $\mathrm{Cd}$ in water. Talanta, 47 (1998) 237-1243.

[8]. Kagaya S., M. Saiki · Z. A. Malek, Y. Araki $\cdot K$. Hasegawa, Coprecipitation with lanthanium phosphate as a technique for separation and preconcentration of iron(III) and lead. Fresenius J Anal. Chem., 371 (2001) 391-393.

[9]. Umashankar V., Radhamani R., Ramadoss K., Murty. D.S.R., Simultaneous separation and preconcentration of trace elements in water samples by coprecipitation on manganese dioxide using D-glucose as reductant for $\mathrm{KMnO}_{4}$, Talanta, 57 (2002) 1029-1038

[10]. Elçi L., Soylak M. And Özcan B., Coprecipitation of $\mathrm{Cu}(\mathrm{II}), \mathrm{Ni}(\mathrm{II}), \mathrm{Fe}(\mathrm{III})$, $\mathrm{Cd}(\mathrm{II}), \mathrm{Pb}$ (II) and $\mathrm{Co}$ (II) in Wastewater, Sediment, and Metallic Zinc Samples with HMDTC-HMA for Flame Atomic Absorption Spectrometric Determination, Analytical Letter, Vol. 36 No. 5 (2003) 987-999.

[11]. Soylak M., Saracoglu S., Divrikli Ü., Elçi L., Coprecipitation of heavy metals with erbium hydroxide for their flame atomic absorption spectrometric determinations in environmental samples, Talanta, 66 (2005) 1098-1102. 
[12]. Kagaya S., Araki Y., Hirai N., Hasegawa K., Coprecipitation with yitrium phosphate as a separation technique for iron(III), lead, and bismuth from cobalt, nickel, and copper matrices, Talanta, 67 (2005) pp 90-97

[13]. Soylak M., Erdoğan N.D., Copper(II)rubeanic acid coprecipitation system for separation-preconcentration of trace metal ions in environmental samples for their flame atomic absorption spectrometric determinations, Journal of Hazardous Materials B, 137 (2006) pp 1035-1041.

[14]. Soylak M., Onal G., Determination of trace metals by atomic absorption spectrometry after coprecipitation with europium hydroxide, Journal of Hazardous Materials B, 137 (2005) 11301134.

[15]. Saracoğlu Sibel, M. Soylak M., Peker D.S., L. Elci L., Santos W.N.L., Lemose V.A., Ferreira S..L.C., A preconcentration procedure using coprecipitation for determination of lead and iron in several samples using flame atomic absorption spectrometry, Analytica Chimica Acta 575 (2006) 133137.

[16]. Saito M. A. And Schneider D. L., Examination of precipitation and improvements in precision using $\mathrm{Mg}(\mathrm{OH})_{2}$ preconcentration inductively coupled plasma mass spectrometry (ICPMS) method for high-throughput analysis of open-ocean $\mathrm{Fe}$ and $\mathrm{Mn}$ in seaawater, Analytica Chimica Acta 565 (2006) 222233.

[17]. Aydın A. F. ve Soylak M., A novel multielement coprecipitation technique for separation and enrichment of metal ions in environmental samples. Talanta, 73 (2007) 134-141.
[18]. Duran C., Bulut V. N., Gundogdu A., Ozdes D., Yildirim N., Soylak M., Senturk H. B., Elci L., Carrier elementfree coprecipitation with 3-phenly-4-ohydroxybenzylidenamino-4,5-dihydro1,2,4-triazole-5-one (POHBAT) for separation/preconcentration of $\mathrm{Cr}(\mathrm{III})$, $\mathrm{Fe}(\mathrm{III}), \mathrm{Pb}$ (II) and $\mathrm{Zn}$ (II) from aqueous solutions, Journal of Hazardous Materials, 167 (2009) 294-299.

[19]. Kagaya Shigehiro, Mizuno Toshiyuki, Tohda Koji, Inductively Coupled plasma atomic emission spectrometric determination of 27 trace elements in table salts after coprecipitation with indium phosphate, Talanta, 79 (2009) 512-516.

[20]. Tokalığlu S. \& Yıldız S., A comparative study on the preconcentration of some metal ions in water samples with $\mathrm{Cu}$ (II) and $\mathrm{Ni}$ (II) salicylaldoxime coprecipitants, Microchim Acta, 165 (2009) 129-133.

[21]. Citak Demirhan, Tuzen Mustafa, Soylak Mustafa, Simultaneous coprecipitation of lead, cobalt, copper, cadmium, iron and nickel in food samples with zirconium(IV) hydroxide prior to their flame atomic absorption spectrometric determination, Food and Chemical Toxicology, 47 (2009) 2302-2307.

[22]. Grotti M., Francesco Soggia S. F., Ardini F.and Frache, R., Determination of subna-nomolar levels of iron in sea-water using reaction cell inductively coupled plasma mass spectrometry after $\mathrm{Mg}(\mathrm{OH})_{2}$ coprecipitation J. Anal. At. Spectrom., 24 (2009) 522-527.

[23]. Saracoglu S., Soylak M., Carrier element free coprecipitation (CEFC) method collector $\mathrm{CTAB}$ for separation and preconcentration of some metal ions in natural water and soil samples, Food and Chemical Toxicology, 48 (2010) 3281333. 
[24]. Uluozlü D. Ö.,, Tuzen M., Mendil D., Soylak M., Coprecipitation of trace elements with Ni(II)-2-Nitroso-1naphthol-4-sulfonic acid and their determination by flame atomic absorption spectrometry, Journal of Hazardous Materials, 176 (2010) 1032-1037

[25]. Sacmac1 S. ve Kartal S., Determination of some trace metal ions in Various samples by FAAS after separation/preconcentration by copper(II)- BPHA coprecipitation method, Original paper, Microchim Acta, 170 (2010) 75-82.

[26]. Soylak M., Aydin A., Determination of some heavy metals food and environmental samples by flame atomic absorption spectrometry after coprecipitation, Food and Chemical Toxicology, 49:6 (2011) 1242-1248

[27]. Tokalıglu S., Ayhanoz H., Use of Cu(II) and $\mathrm{Fe}(\mathrm{III}) \quad \mathrm{N}$-benzoyl-Nphenylhydroxylamine coprecipitants for preconcentration of some trace metal ions in food samples, Food Chemistry, 27 (2011) 359-363

[28]. Mendil D., Karatas M., Tuzen M., Separation and preconcentration of $\mathrm{Cu}(\mathrm{II}), \mathrm{Pb}(\mathrm{II}), \mathrm{Zn}$ (II), $\mathrm{Fe}(\mathrm{III})$ and $\mathrm{Cr}$ (III) ions with coprecipitation method without carrier element and their determination in food and water samples. Food Chem., Jun 15; 177 (2015) 320-324. 